\title{
From the Pen of the Editor Ralph Scott
}

I recently read a survey article in the May 2008 issue College and Research Libraries entitled "Transitions Faced by New Academic Librarians." In this recent survey an open-ended question was asked: "What was the Hardest Thing to Learn" as a new professional. Major themes cited were: workplace politics/ culture; "How to get things done;" collection development; local procedures, resources and structures; time management/ workload management; "Saying no;" conflict management; and "relationships with faculty." Interestingly these were the same issues I faced when I entered the profession over thirty years ago. I guess the old French adage quoted by Shaw in the Revolutionists Handbook, "The more things change the more they stay the same," applies to librarianship.

I think however that we must do a better job in the future. The increase in mentoring activities in many libraries will help, but we all need to be more proactive in helping our new colleagues. Library Schools need to do a better job in the instruction of management skills to new librarians. While local procedures and cultures will vary from library to library, what we can teach are the skills to use in discovering and adapting to a new job. Often we assume that new librarians parachute into a new job knowing everything there is to know about collection development. Collection development is such an opened ended task that people need techniques for resources management rather than specific bibliographic tools. Coping with colleagues and faculty are people skills that we have not done a good job of mentoring new librarians in. New librarians face the same challenges anyone faces on a new job. We are not alone in this problem. For example, engineers and other professionals face much the same issues we do: http://www. asme.org/Communities/EarlyCareer/Transitions/Job 3.cfm New librarians often complain "I don't know what it is that I am supposed to do here?" Well, begin by asking what is expected. Better to do this sooner rather than later (yet another French adage!) Ask for a job description. Ask what the ethical climate is in the organization. What are the benefits and expectations of the job (sometimes this is a good idea of ask about before you take the job!) I often counsel people who have been on the job for five and six years, and they are still trying to figure out what it is they are expected to do. Finally ask yourself "Is this where I want to spend the next thirty years" (you never know, you may not get a better offer!). Finally studies have shown that people stay on the job not because they like the compensation, but because they like the workplace environment. Hopefully techniques like successful mentoring will help explain the local environment to those new to the profession.
$\mathrm{N} O \mathrm{R} \mathrm{T} \mathrm{H}$
CAROLINA

LIBRARIES

EDITOR Ralph Lee Scott scottr@ecu.edu

ASSOCIATE Terry W. Brandsma

EDITORS Anne Coleman Joline R. Ezzel Mike Van Fossen Page Life Jane S. McAllister Eileen McGrath Elizabeth H. Smith Jennifer Smith Larry Nash White Rob Wolf Jamane Yeager

AUTHORS Bobbie L. Collins Eileen McGrath Ralph Lee Scott Elizabeth H. Smith Kynita Stringer-Stanback Rosalind Tedford Robert Wolf H. David Womack

CONTRIBUTORS Robert Burgin Kathryn Stripling Byer GladysAnn Wells

INDEXER Mike Van Fossen LAYOUT Michael Reece
Letters to the editor should be addressed to the editor and sent to Joyner Library, East Fifth Street, Greenville, NC 27858, or by electronic mail (scottr@ecu.edu). We reserve the right to edit all submissions. If you are interested in writing for North Carolina Libraries or would like consideration for news and product information, please send brief information to the editor at the above address. http://www.nclaonline.org 